Ирина Попова-Бондаренко

ORCID: 0000-0003-4751-5557

Донецкий национальный университет

Донецк, Украина

\title{
Коды «мужского» и «не-мужского» \\ в художественном мире Morpho Eugenia A.С. Байетт
}

https://doi.org/10.34739/clit.2021.15.16

\section{Masculine and Non-masculine Codes in the Imaginative Integrity of Morpho Eugenia by A.S. Byatt}

Morpho Eugenia is the first part of the postmodernist novel Angels and Insects by A.S. Byatt. The male world is represented here in abundance by numerous names of famous naturalists, philosophers and poets of the XVII-XVIII centuries and of Victorian England, as well as by the male characters of the novel. It is pointed out that the concepts of "masculine" and "non-masculine" in the novel presuppose double reading, namely, the traditional (Victorian) and posttraditional one (neoVictorian). In the neo-Victorian interpretation, most of the male characters in the novel are devoid of traditional masculine qualities (honor and dignity, commitment to the cause, inner strength), they bear a stigma of vice (incest), while the "male organization" features of the central female character, non-typical for a Victorian woman (talent, efficiency, perseverance, energy, self-reliance), contribute to the formation of an integral harmonious world of men and women as friends, lovers, like-minded people.

Keywords: A.S. Bayett, "masculine", "non-masculine", vice, work, female talent, perseverance, dignity, universal human qualities

Антония Сьюзен Байетт (род. в 1936 г.), обладательница целого ряда литературных премий, среди которых - Букеровская (1990), премия О'Генри (2003) и другие - по праву считается одной из выдающихся писательниц современности.

Morpho Eugenia (Морфо Евгения) входит в состав произведения Байетт Ангель и насекомые (Angels and Insects, 1992), относительно жанра которого до сих пор не выработано окончательного 
представления: его называют и повестью, и романом. Не останавливаясь специально на родо-жанровой природе произведения, так как это не является предметом нашей статьи, отметим, что мы больше склоняемся всё же к романной форме. Произведение Ангелы u насекомые двучастно: первая часть, которой мы, собственно, и уделим внимание, называется Морфо Евгения, вторая - Ангел супружества. Подчёркнутая архитектоническая автономность частей нарушается посредством почти неуловимых композиционных скреп наличием «сквозных» периферийных героев (постмодернистский эффект децентрации) и обстоятельств, обеспечивающих общий для всего романа концептуальный срез: приоритетность любовного чувства, основанного на благородстве, верности и духовной общности.

Творчество А.С. Байетт чаще всего относят к так называемой неовикторианской литературе, которую различные исследователи именуют и викторианской ${ }^{1}$, и достаточно общо - как «яркое и необычное явление в современной английской литературе», в котором взаимодействуют элементы различных литературных направлений (постмодернизм, реализм, модернизм, романтизм) и которому присущ мощный психологизм ${ }^{2}$. Практически во всех произведениях писательницы сталкиваются и причудливо взаимодействуют две эпохи - викторианская с её традиционными представлениями о мужском начале как манифестации силы и благородства и женском (слабом, зависимом, беззащитном) и неовикторианская (посттрадиционная). Последняя отмечена закономерной ревизией традиционной (викторианской) системы знаний и представлений, в частности, касающихся доминирующего положения мужчины в викторианской системе координат и приписываемых ему (мужчине) достоинств. И в этой связи следует заметить, что, критикуя устои и ханжеские нравы викторианского общества, Байетт отталкивается от классического английского романа

\footnotetext{
${ }^{1}$ O.А. Толстых, Английский постмодернистский роман конца ХХ века и викторианская литература: интертекстуальный диалог: на материале романов А.С. Байетт и Д.Лоджа, Автореф. канд. дисс., Екатеринбург 2008, с. 4-5, https://www.dissercat. com/content/angliiskii-postmodernistskii-roman-kontsa-xx-veka-i-viktorianskaya-literaturaintertekstualn [дата доступа: 26.11.2020].

2 М.Н. Конькова, Поэтика жанра рассказа в творчестве А.Байетт, Автореф. канд. дисс., Екатеринбург 2010, с. 3, 14, https://www.dissercat.com/content/poetika-zhanra -rasskaza-v-tvorchestve-baiett/read [дата доступа: 09.01.2021].
} 
(Филдинг и Дж. Остин), учитывая в то же время и точки зрения отечественных постмодернистских авторов, которые обращались к викторианской тематике (Фаулза, Бейнбридж, Акройда и др.), где в аксиологический центр также выдвигаются не сословные, половые или гендерные характеристики мужского начала (или соответственно - женского), но этические и душевные качества героев.

Сложная художественная организация Морфо Евгения соответственно требует использования ряда методологических положений и практик - художественно-коммуникативного аспекта (или, по словам У. Эко, «эстетической коммуникации» с выведением на поверхность понятия «код»), герменевтического подхода (толкование с учётом литературной традиции), практики close reading и др.

В перспективе особый интерес могли бы представлять изыскания и в русле деконструктивистской практики на материале оригинального текста романа, который представляет широкое поле «озна́чивания» (Ж. Деррида), когда «смысл догоняет интерпретатора» (Ю. Матони), но эта задача требует отдельного вдумчивого подхода.

Под художественно-эстетическим кодом «мужского» и/или «немужского» понимается широкий «репертуар» (выражение В. Изера) сигналов и смыслов, который в постмодернистском произведении Байетт приобретает плюральный, ризомный характер. Всё, что в романе внешне обозначено как «мужское», вовсе не обязательно должно быть отнесено к мужчине, равно как «женское» - только к женщине как к «половым существам» (Н. Бердяев). Так, «мужское» может подвергаться глубинной ценностно-смысловой деформации и неожиданно обнаруживаться в «женском» - т.е. в своей резко маркированной согласно викторианской морали противоположности, что в полной мере и проявлено в произведении.

Мир Морфо Евгения предельно насыщен мужским началом. То и дело в тексте мелькают известные имена - философа Дж. Рёскина, английского энтомолога Генри Уолтера Бейтса, друга и коллеги Бейтса, естествоиспытателя Альфреда Уоллеса, шотландского садовода и архитектора малых парковых форм Дж. Лудона, немецкого натуралиста и путешественника Александра фон Гумбольдта, В.Г. Эдвардса, Дарвина, священника и философа-идеалиста Вильяма Пейли, английского экономиста 1830-х годов доктора Эндрю Ура, английского социалиста-утописта Роберта Оуэна, историка Вильяма 
Уэвела, Мильтона и поэта-викторианца Альфреда Теннисона и многих других. Эти имена охватывают практически все сферы английской интеллектуальной жизни от XVII в. до второй половины XIX века: философию, естественные науки, архитектуру, поэзию, живопись...

Степень концентрации упомянутых выше общеизвестных деятелей столь высока, что, можно сказать, в полной мере представляет мужскую «викторианскую вселенную» открытий, находок и творчества.

Исторически зафиксированные имена мужчин, оставивших свой след в европейской науке и искусстве, составляют в романе некий фон, на котором в Морфо Евгения действуют центральные герои-мужчины и второстепенные мужские персонажи.

Сразу же отметим, что «мужской» код в произведении понятийно не вербализован, не прописан и не представлен в окончательно оформленном виде, а словно «рассыпан» по всему художественному миру романа. Мужские качества, считавшиеся истинными в глазах представителей викторианской эпохи (благородство, честь, служение делу, внутренняя сила, джентльменское отношение к женщине), в произведении изначально делегированы мужской аристократии и воспринимаются как нечто само собой разумеющееся.

Итак, прежде всего обратимся к антропонимическим и портретным характеристикам мужчин в Морфо Евгения. Первый из них - натуралист Вильям Адамсон, только что вернувшийся из небезопасного путешествия по Бразилии, побывавший в амазонских вечнозелёных лесах и чудом выживший в кораблекрушении на обратном пути в Англию. Английское имя William восходит к германскому Wilhelm, в котором соединено столь важное для мужчины значение воли (wil) со шлемом (helm), что формирует представление о герое как человеке надёжном и постоянном, каким, собственно, он и останется в глазах читателей, подтвердив поступками свой антропонимический «аванс», однако не без помощи извне, о чём будет сказано далее.

Любопытно, что портретное описание Вильяма Адамсона даётся постепенно, в два приёма. Первое (прямое) подчёркивает контраст между перенесшим невзгоды Вильямом, попавшим, как говорится, «с корабля на бал», на семейный танцевальный вечер Алабастеров, и белокожими изнеженными обитателями этого богатого английского 
поместья, куда по возвращении герой был приглашён хозяином дома - священником и натуралистом-любителем сэром Гаральдом: «Здесь (...) из-за своего золотистого, немного желтушного загара он казался смуглым. Высокий, от природы очень худой, после тяжких испытаний на море он походил на покойника»3.

Второе описание Вильяма можно отнести к разряду опосредованных, так как оно соотнесено с его отцом, Мартином Адамсоном, черты которого находят отражение и во внешнем облике Вильяма. Здесь же представлен краткий очерк становления главного героя - уровень его образованности и научный склад ума (например, прилежание, трудолюбие, способность к обобщению и классификации):

Его отец, богатый мясник и непоколебимый методист, определил сыновей в хорошую местную школу, где они освоили греческий, латынь, основы математики, и требовал, чтобы братья ходили в церковь. Вильям, уже тогда любивший все классифицировать, подметил, что мясники, как правило, люди в теле, шумные и упрямые. у Мартина Адамсона, как и у сына, была грива темных блестящих волос, длинный и крепкий нос и зоркие голубые глаза под прямой линией бровей. (...) Возлагая большие надежды на будущее Вильяма, тем не менее ни к чему конкретному он его не склонял, лишь бы его профессия была хорошей и с перспективой роста4.

Окружающие (в частности, хозяин поместья, сэр Гаральд Алабастер и соседи), чуждые Вильяму по взглядам и образу жизни, явно льстят ему, находя в нём черты благородства и великодушия, безграничность «выносливости и силы духа», как выразилась леди Алабастер, отмечают его работоспособность и профессиональную увлечённость. Вильям - учёный-натуралист, труженик, сделавший себя сам, человек из простого сословия, как говорят в таких случаях, «от земли», что подчёркивается и символикой его фамилии - Адамсон (антропогонический мифологический мотив, связующий Вильяма Адамсона и библейского, а также коранического Адама, созданного из праха/земли/глины). Загорелый в экспедициях, смуглый Адамсон полная противоположность аристократическому семейству

\footnotetext{
3 А.С Байетт, Морфо Евгения, здесь и далее используется русский перевод Михаила Наумова - https://www.litmir.me/br/?b=53053\&p=1 [дата доступа: 05.11.2020].

4 Ibidem.
} 
Алабастеров, в облике и родовом имени которых заключена красота и холодность (Alabaster - 'алебастр', в переводе с древнегреческого $\alpha \lambda \alpha \beta \alpha \sigma \tau \rho о \varsigma$ - белый полупрозрачный и прохладный минерал, из которого вытачивают скульптуры, вазы и прочие артефакты):

У девушек были светло-золотистые волосы и матовая кожа, большие синие глаза обрамлены светлыми, шелковистыми ресницами, которые можно было разглядеть, если на них падал свет. (...) У братьев девушек были такие же золотистые кудри и матовая кожа. Вместе они составляли очаровательную однородную группу5.

Код мужественности в отношении Вильяма, как видим, исподволь формируется в качественном плане (перечисление достоинств героя), хотя никто из окружающих прямо не называет Вильяма «настоящим мужчиной». Но всё же перечисленные выше позитивные мужские качества Вильяма, которые, казалось бы, должны раз и навсегда определять его поведение, несколько подтачиваются целым рядом не вполне мужских проявлений характера. Так, герой нерешителен и склонен к рефлексии, подвержен минутам слабости (что находит отражение в его дневниковых записях), порой не вполне уверен в своём профессионализме. Ему, опытному натуралисту и классификатору, недостаёт полезного в определённых случаях здравомыслия и логики: он совершает одну из самых непростительных ошибок, позволив прекрасной (и, как потом станет очевидным, развратной) Евгении, старшей из дочерей Алабастеров, обольстить его и женить на себе. В нём обнаруживается и отсутствие внутреннего стержня для того, чтобы вынести «сор из избы» - во всеуслышание заявить о подлости Эдгара Алабастера (брата Евгении), совратившего малолетнюю служанку Эми, удалённую затем из дома по причине беременности. Неудавшийся разговор с Эдгаром по поводу «затяжелевшей Эми», в ходе которого Вильям спасовал, «пробудил в нём непомерно сильный и неодолимый мужской стыд за свою беспомощность и бессилие» ${ }^{6}$.

Хозяин поместья - Гаральд Алабастер - и вовсе не оправдывает высокого предназначения, которое заложено в его имени (Harald), что ассоциируется с военными подвигами (Harald - дословно:

5 Ibidem.

${ }^{6}$ Ibidem. 
'военачальник'). На деле же он безынициативен и вял, погружён в бесплодные размышления о роли всепроникающей любви Творца и развивает эту тему в своих рукописях, которые время от времени даёт прочесть Вильяму, явно ожидая отзыва или подталкивая к философской дискуссии. Отпрыск благородного рода, Гаральд был младшим сыном, а потому в своё время принял согласно тогдашним обычаям духовный сан.

Временами, когда его голова была вскинута, а на белые пряди бороды падал свет, он - пронзительным взором, белоснежной сединой волос, древностью - напоминал Бога Отца. Иной раз, когда он вел речь спокойно и едва слышно, устремив взгляд на шахматные клетки пола, он казался почти жалким; неопрятна была и его старая поношенная мантия. Случалось, что на миг он представлялся Вильяму португальским монахом-миссионером, - с ними ему приходилось встречаться на Амазонке, то были исхудавшие до крайности люди с горячечным взглядом, которые тщились разгадать причину непонимания со стороны умиротворенноравнодушных индейцев 7 .

Заметно, что в пределах одного пассажа заключены взаимоисключающие характеристики: Гаральд, напоминающий Бога Отца (или пророка), и Гаральд - миссионер-ортодокс с неистовой горячечной верой, присущей монашескому ордену. Уже внешне он напоминает эту оторванную от жизни касту:

Гаральд Алабастер был высок, сухопар и сутуловат. Его лицо, худое, цвета слоновой кости, носило фамильное сходство с его детьми; слегка водянистые синие глаза, которые чуть слезились, рот прятался в пышной патриархальной бороде. И борода, и длинные густые волосы были почти седые, но кое-где уцелевший светло-русый цвет сообщал им неожиданно тусклый латунный оттенок. Алабастер носил свободную черную куртку с жестким стоячим воротничком и мешковатые брюки, а поверх - нечто вроде монашеской сутаны из черной шерсти с длинными рукавами и капюшоном $(. . .)^{8}$.

И постоянно холодный кабинет сэра Гаральда (явная отсылка к диккенсовской параллели «холодного дома» - холодной души), и весь его внешний вид свидетельствует об угасании в нём не только

7 Ibidem.

8 Ibidem. 
мужского, но и интеллектуального начала: Вильям потрясён тем, как небрежно Гаральд Алабастер относится к бесценным энтомологическим и зоологическим находкам, которые попадают в его дом буквально со всех концов света. Ради этих редких экземпляров натуралисты рисковали зачастую своей жизнью, а теперь многие раритеты пребывают в ужасном состоянии, и Вильяму предстоит привести в порядок весь этот крайне запущенный материал и сформировать коллекцию. Но самым неприятным (и отчасти унизительным) открытием для Вильяма становится постепенное осознание того, что, входя в семью на правах мужа Евгении, этакого «бедного родственника», он должен расплачиваться за эту честь с сэром Гаральдом своим интеллектом - знаниями, открытиями, гипотезами.

Неслучайно в описании сэра Гаральда особое внимание уделено его слезящимся глазам, что становится метафорой не столько старости и немощи, сколько душевной слепоты. И действительно, этот человек, посвятивший огромное количество времени разработке важнейшего этического вопроса о Божественной и всечеловеческой любви, которая обымает всех людей, уподобляя их единому семейству, где царят любовные отношения между родителями, братьями и сёстрами, попросту слеп. Он не видит (или, что ещё страшнее, - не желает замечать) тех противоестественных отношений, которые связывают Эдгара (его сына от первого брака) и Евгению (дочь от второго брака). И когда он произносит свои речи «о любви к ближнему» в домовой церкви, они начинают приобретать ужасный двойной смысл, который в недалёком будущем станет внятен и Вильяму.

Проповеди Гаральда, иронично замечает автор, «были добрыми». В них говорилось о любви к Богу Отцу, который, желая сделать более понятной для «человеков» свою любовь к ним, учит их постигать любовь «на примере естественных уз, связывающих членов семьи, материнского тепла и отцовского покровительства, братской и сестринской близости (...)»9. Упомянутая в проповедях «братская и сестринская близость» на поверку оказывается слишком буквальной, слишком фактуальной - инцестуальной, то есть извращающей всю Богоустроенную природу высоких человеческих отношений.

\footnotetext{
9 Ibidem.
} 
Тревожная нота тщательно скрываемого семейного неблагополучия усилена в сцене проповеди и на визуальном уровне - светом солнца, который проникает сквозь стёкла церкви, обливая пурпуром дремлющую на скамье мать Евгении, леди Алабастер, что заставляет имплицитного читателя вспомнить о зеркальном перевёртыше мотива царственной багряницы (пурпура, порфиры) в книге Откровения Иоанна Богослова: именно в эти одежды облечена там вавилонская блудница как «мать блудницам и мерзостям земным»10. А высокие церковные витражи, на которых изображены синие (читай: винные) виноградные гроздья (языческий мотив разгула и опьянения) и кремовые лилии (цвет кружев свадебного платья Евгении, которую к жениху подведёт её брат и любовник Эдгар) словно взрывают благочестивую атмосферу проповедей оргиастической символикой.

Водянистые слезящиеся глаза Гаральда, его длинные волосы, старая поношенная мантия, пустые речи, а главное - холодное равнодушие и сердечная слепота - всё это суть концептуальные маркеры его бесполости и духовной импотенции, маркеры «немужского».

Но в Morpho Eugenia представлены и иные мужчины, существование которых в определённом смысле хотя внешне и компенсирует бесцветность сэра Гаральда, но по сути также не соотносится с задекларированным викторианской средой «мужским» началом. С этими героями читатель знакомится уже в сцене танцевального вечера - это братья Лайонел и Эдгар Алабастеры, дети Гаральда от первого брака. Поведение первого из них (Лайонела), молодого капризного сибарита, полного нерастраченных жизненных сил, укладывается в расхожее представление о «мужском» образе жизни аристократа (к его увлечениям относятся верховая езда, охота, курение сигар и болтовня в мужских компаниях), что вполне соответствует и поэтике его имени - известно, что Lionel обычно трактуется как «львёнок» (и здесь проступают явно анималистические коннотации игр молодого хищника).

Значимую же роль в произведении играет Эдгар, единокровный брат Евгении по отцу, сэру Гарольду. Поэтика его имени в контексте Морфо Евгения обнаруживает признаки парадоксальности.

10 Откровение святого Иоанна Богослова (17:4-5), [в:] Библия. Книги священного писания Ветхого и Нового Завета. 
Древнеанглийское имя Edgar включает два смысловых компонента: ed (ead) соотносится со счастьем, a gar - с копьём. Наиболее частотная трактовка этого имени - «воин, которому сопутствует удача».

И действительно, в описании танцующего Эдгара на первый план выдвигается его мужская стать, сила и ловкость:

Эдгар Алабастер танцевал со своей сестрой Евгенией. Эдгар был крупным, мускулистым мужчиной. Его светлые волосы, волнистыми прядями обрамлявшие продолговатое лицо, колыхались в потоках воздуха; держался он очень прямо. Его большие ступни быстро двигались в замысловатых па в унисон с жемчужносерыми башмачками Евгении, непринужденно и плавно выписывая фигуры вальса. Они танцевали молча. Эдгар с выражением легкой скуки на лице пробегал взглядом по бальному залу ${ }^{11}$.

Однако этот «мужской код» (сила, стать) довольно быстро подвергается этической коррозии - Эдгар (как, впрочем, и его брат) жесток:

С наступлением зимы молодые люди оживились. Эдгар и Лайонел целые дни проводили вне дома, стреляли или охотились, возвращались с окровавленной добычей - птицей и зверем; нередко и руки их, и одежда тоже были в крови ${ }^{12}$.

В произведении часто упоминаются кодексальные в аристократических сообществах охотничьи вылазки, на которые Вильяма обычно не приглашают, потому что он из другого круга. Впрочем, Вильям и сам далёк от подобных кровавых развлечений. Учёный, натуралист, он трепетно относится ко всему живому: восторгается хрупкой красотой бабочек и изящными формами муравьиных «атлетов», которые способны перетаскивать огромные по сравнению с их размерами грузы. Для него, побывавшему в экспедициях и часто смотревшему в глаза смерти, всё живое обладает непреложной ценностью. Простолюдин по рождению, высокомерно отторгаемый аристократическим семейством, Вильям душевен, благороден и добр.

Эдгар же начисто лишён благородства, несдержан, его лицо часто перекашивает злоба, а в Вильяме, готовящегося к свадьбе

\footnotetext{
${ }^{11}$ А.С Байетт, Морфо Евгения..., ор. cit.

12 Ibidem.
} 
c Евгенией, он видит соперника. По мере развития любовноинцестуальной интриги в облике Эдгара всё больше проступает животное начало (английское brute, мысленно адресованное Вильямом Эдгару, вполне можно перевести и как «животное»). Один из персонажей называет Эдгара кентавром (centaur) и сатиром (satyr), а в одной из финальных сцен романа, когда Вильям застаёт Эдгара в постели с Евгенией, тот и вовсе издаёт звериное глухое рычание (stifled bellow).

Любитель верховой езды, Эдгар и сам уподобляется коню, а точнее - жеребцу (stallion):

Эдгар держал гнедого арабского жеребца с изогнутой, мускулистой атласной шеей. Жеребца звали Саладин; в полутьме стойла он сверкал глазами и переступал с ноги на ногу, скаля зубы. Айвенго, так звали охотничью лошадь Эдгара, огромный серо-стальной жеребец, был хорошо откормлен и отменно брал барьеры. Не было случая, чтобы Эдгар отказался на пари взять с Айвенго самое невообразимое препятствие, и конь всегда оказывался на высоте. Они походили друг на друга - оба мускулистые и высокие; оба распираемые едва сдерживаемой силой ${ }^{13}$.

Спустя некоторое время Вильям вновь отмечает в облике Эдгара схожесть с жеребцом: «На висках и шее Эдгара вздувались жилы. Он, как и его конь, был сильным, неуравновешенным животным. Рассказывая, он то понижал голос до мелодичного бормотания, то начинал надрывно кричать (...)»14. Автор романа далеко не случайно затрагивает «лошадиный» мотив, который отсылает читателя не только к коду низкой животной маскулинности (жеребец, самец), но и к библейской символике, углубляя тем самым радикальное противоречие между кажущейся викторианской пристойностью и греховной безнравственностью. Остановимся на этом более детально. В Морфо Евгении неоднократно подчёркивается увлечённость всех молодых Алабастеров верховой ездой. Но в описании лошадей, принадлежащих инцестуальной паре (Эдгару и Евгении), важную роль играет цветовая гамма, косвенно отсылающая к апокалиптическим животным. У Эдгара - два жеребца: гнедой (chestnut) Саладин и серо-стальной (iron-grey) Айвенго,

13 Ibidem.

14 Ibidem. 
у Евгении - вороная кобыла Ночка (black mare Dusk). При ближайшем рассмотрении окрас лошадей приобретает знаковый характер: он вызывает ассоциации с конями всадников Апокалипсиса. Так, гнедой конь бывает чаще всего рыжего оттенка различной насыщенности, а учитывая яркий блеск (gleamin) шерсти Саладина, он огненно-рыжий. Иными словами, переведя рассуждения в символическую плоскость, можно предположить, что и конь, и его всадник привносят в буколический мир поместья войну и раздор, что, собственно, подтверждается всеми действиями Эдгара - его заносчивостью, нетерпимостью, своенравием, порочностью, агрессивностью, жестокостью (ср. выше описание окровавленных рук и одежды после охоты).

Серо-стальной жеребец Айвенго максимально приближен по масти к тому, кого в Откровении Иоанна Богослова именуют «бледным конём»: «(...) и вот, конь бледный, и на нём всадник, которому имя смерть; и ад следовал за ним» 15 .

Чёрная кобыла Евгении в данном ряду заставляет вспомнить о «коне вороном», традиционно олицетворяющем голод (а согласно иным толкованиям - голод и смерть). Но в случае с Евгенией - это голод ненасытной страсти, чувственности и похотливости, которые она не может и не желает усмирить. В обозначенном ассоциативном поле рядом со страстью соприсутствует и смерть - она связана с сюжетной линией первого жениха Евгении, капитана Ханта, который покончил с собой, узнав о связи своей «непорочной» невесты с её братом, Эдгаром.

Казалось бы, для полноты эсхатологической картины недостаёт ещё одного - четвёртого коня из Откровения Иоанна Богослова. Как известно, апокалиптический белый конь связан с мором (болезнью, эпидемиями). И всё же его образ неожиданно обнаруживается в повествовании, будучи выведенным, в духе поэтики постмодернистского романа Байетт, за пределы читательского «фокуса зрения». В конце романа, когда открывается вся правда, Вильям с плохо сдерживаемой брезгливостью осознаёт, что Евгения рожает пятерых детей не от него, а от Эдгара, и дети наследуют весь генетический код семейства Алабастеров - беленькие, похожие друг на друга, с младенческим лебединым пушком на головах. Белизна, как

\footnotetext{
15 Откровение святого Иоанна..., ор. cit.
} 
видим, варьирует от родовой семантики (Alabaster - белый) до видовой (молочно-белый цвет кожи младенцев). Но поистине удивительное, виртуозное сцепление смыслов наподобие барочного консепта читатель встречает в сцене разрыва Вильяма и Евгении. Именно здесь вербализуется анималистическая параллель: Евгения самка, кобылица, лошадь. «Коннозаводчики знают, - сказал Вильям, - что даже двоюродных лошадей лучше не спаривать - это чревато наследственными дефектами» ${ }^{6}$. В устах натуралиста словосочетание «наследственные дефекты» звучит как приговор всему роду Алабастеров, которому грозит вырождение от инбридинга близкородственного скрещивания. Так реминисцентно формируется образ того самого белого коня из Откровения Иоанна, который принесёт мор и гибель развратному семейству Алабастеров.

Как ни парадоксально, но истинно твёрдые качества, не подвергающиеся девальвации ни при каких обстоятельствах, в романе выказывает не мужчина, но женщина - Мэтти (Матильда) Кромптон: «Она не была ни гувернанткой - эти обязанности исполняла мисс Мид, - ни няней, как Дакрес, хотя младшие члены семейства находились под её опекой»17. Уже портретная характеристика Мэтти Кромптон составляет оппозицию всему женскому клану Алабастеров отяжелевшей плодовитой матери, леди Алабастер, и нежным, бледным очаровательным сёстрам, напоминающим, скорее, мотыльков, чью воздушность и хрупкость подчёркивают их туалеты, где преобладают белые, голубые, лимонные оттенки муслина, шёлка, тюля и газа.

В сравнении с женщинами и детьми семейства Алабастеров стиль одежды Мэтти, помогающей Вильяму в научном эксперименте (наблюдении за колонией муравьёв), отличается деловитой простотой, обличающей в ней натуру демократичную, незаурядную, самодостаточную, привыкшую, как и Вильям, всего добиваться свои трудом: «(...) в немодном черном платье с аккуратными белыми манжетами и белым воротничком (...)»18; или: «На ней было коричневое шерстяное платье, строгое, без отделки»19; или:

\footnotetext{
${ }^{16}$ А.С Байетт, Морфо Евгения..., ор. cit.

17 Ibidem.

18 Ibidem.

19 Ibidem.
} 
На ней была коричневая юбка и полосатая блузка с закатанными по локоть рукавами. Ее лицо затеняла старенькая соломенная шляпа с мятой малиновой лентой; в этой одежде она выходила наблюдать за муравьями. К тому времени Вильям составил представление о ее гардеробе; он не был обширен: на лето пара хлопчатобумажных юбок и воскресное платье из темно-синего поплина с набором белых крахмальных воротничков да несколько коричневых и серых блузок ${ }^{20}$.

Нетривиальна и внешность Мэтти:

Высокая и стройная (..). Ее лицо было худощаво и неулыбчиво, кожа в тон темным, заправленным под простой чепец волосам - смуглая ${ }^{21}$. (..) Темные волосы были заплетены в косы и уложены вокруг головы ${ }^{22}$. (...) Она, как птица, была остроглаза и наблюдательна 23.

Нравственно и душевно Мэтти Кромптон противостоит не только женской аристократической половине, но и бездеятельным мужчинам Алабастерам - белокурому порочному Эдгару, капризному Лайонелу и их седовласому индифферентному отцу, «почтенному» сэру Гаральду. Вильям отмечает её проницательность, работоспособность, ум (прекрасное знание английской литературы, латинского и древнегреческого языков) и талант, увидев, как Мэтти, помогая ему в оформлении будущей научно-популярной книги о естественной истории муравьёв, быстрыми уверенными движениями делает зарисовки «муравьиной жизни»:

Он просмотрел ее тщательно вычерченные рисунки, сделанные карандашом и индийскими чернилами: муравьи едят, муравьи дерутся, муравьи, привстав на задние лапки, отрыгивают нектар и передают его товарищу; муравьи поглаживают личинки и таскают яйца ${ }^{24}$.

Оставаясь в душе женственной, ранимой и глубоко чувствующей, Мэтти, тем не менее, умеет держать себя в руках, а главное - отдаваться работе всецело, продуктивно, по-мужски. В один из жарких дней во

\footnotetext{
20 Ibidem.

${ }^{21}$ Ibidem.

22 Ibidem.

23 Ibidem.

24 Ibidem.
} 
время её зарисовок на пленере Вильям даже чувствует исходящий от её разогретого тела острый запах пота - запах нелёгкого труда. Среди обслуживающего персонала усадьбы антиподом Мэтти становится пожилая гувернантка мисс Мид, которая учит юных Алабастеров хорошему тону и старается их несколько образовывать в викторианском духе. Так, во время наблюдений девочек за муравьями, мисс Мид мечтательным голосом заводит назидательный рассказ о том, как муравьи помогли Психее избежать наказания со стороны богини Венеры, отсортировав семена пшеницы, мака, бобов и проч.

Рассказ мисс Мид об Амуре и Психее, манерный и слащавый, явно выдержан в духе пародии на «чиклит» (Chick Lit)25, но в его худшем, примитивном масскультурном варианте - женского литературного письма милых «цыпочек».

Читатель встречает в этой сказке привычные для третьесортной женской прозы красивости, примелькавшиеся литературные штампы: здесь и оставшаяся на утёсе в ожидании страшной участи быть погубленной змеем «бедная девушка», неизменно прекрасная, «одетая в кружева, в венки из цветов и с нитками чудных жемчужин», и великолепный дворец, куда она была перенесена волшебной силой Амура (Купидона), дорогое угощение и роскошь обстановки, «сладчайшие и нежнейшие» уверения какого-то прекрасного голоса в том, что муж осчастливит девушку, если она ему доверится, и что их счастье будет вечным при условии, что она не станет пытаться его увидеть ${ }^{26}$.

В романе сталкиваются два вставных текста, два типа женского письма - манерного, жеманного викторианского детского «чтива» (устное переложение гувернанткой античной истории об Амуре и Психее) и увлекательного развивающего научно-популярного чтения, когда Мэтти пишет сказку для юной читательской аудитории об этимологии имени Церура винула (Cerura vinula), одного из видов ночной бабочки. Мэтти затем издаст цикл своих сказок, что сделает девушку материально независимой - и это явное переформатирование

\footnotetext{
25 См. глубокое исследование: Ю.Г. Ремаева, Постфеминистская проза Британии на рубеже XX - XXI вв. (феномен «чиклит»). Автореф. канд. дисс., Нижний Новгород 2007, c. 11, 18, https://www.dissercat.com/content/postfeministskaya-proza-britanii-narubezhe-xx-xxi-vv-fenomen-chiklit [дата доступа: 30.11.2020].

${ }^{26}$ А.С Байетт, Морфо Евгения..., op. cit.
} 
и викторианских исторических реалий (полная материальная зависимость женщины от мужчины), и традиционных викторианских представлений о «слабой» женщине, которая не умеет распорядиться своим состоянием и в полном соответствии с тогдашними законами отдаёт его в руки мужчины (отца, братьев, мужа).

Вместе с тем не стоит воспринимать вставной рассказ мисс Мид лишь как пародию на «фемининную» (женскую) литературу. При полной профессиональной несостоятельности эта претенциозная «fairy tale» («волшебная сказка» - термин М.Н. Коньковой ${ }^{27}$ ) играет важнейшую композиционную роль. В ней, как в зеркале, отражаются настоящие и будущие события в жизни Вильяма Адамсона, только поданные не в мужском, а в женском варианте - его постепенного вхождения под своды зачарованного роскошного замка (читай: готической усадьбы Алабастеров), где его опутают «шелковистыми» нитями - узами брака с прекрасной и порочной Евгенией:

Вильям чувствовал себя одновременно беспристрастным антропологом и сказочным принцем, которого удерживали в заколдованном замке незримые врата и шелковые узы ${ }^{28}$.

«Fairy tale» мисс Мид пересекается, в свою очередь, со сказкой Мэтти Кромптон, где появляется околдованный прекрасной волшебницей Сет - в нём пробуждается решительное мужское начало благодаря помощи незаметного муравьишки, в образе которого столь явственно угадываются черты самой Мэтти - хрупкой, но выносливой, благородной, самоотверженной и талантливой. Именно она добровольно и анонимно берёт на себя функции секретаря Вильяма, вступает в переписку с издателями его «муравьиной книги», договаривается о выгодной продаже образцов, реализует свои сказки и по-товарищески (sig!) предлагает материальную помощь Вильяму, выбитому из жизненной и финансовой колеи открывшейся ему страшной семейной тайной. Наконец, она списывается с капитаном, чъё судно отправляется из Ливерпуля в Рио, - именно на нём Матильда и Вильям, сделав свой выбор в пользу науки, поплывут в тропики, чтобы там жить и заниматься энтомологией. Возлюбленные, товарищи, однодумцы. В финале романа девушка

${ }_{27}$ М.Н. Конькова, Поэтика жанра..., ор. сіt., с. 6.

${ }^{28}$ А.С. Байетт, Морфо Евгения, ор. cit. 
зовётся уже не по-домашнему - Мэтти, но Матильдой - то есть «победительницей» (такова семантика этого древнегерманского имени). Именно её внутренняя душевная сила, взрывающая закреплённые в викторианской традиции представления о «мужском как сильном» и «женском как слабом», а именно: развитой ум, тяга к самосовершенствованию, любовь и самоотверженность помогают и Вильяму стать полноценной личностью, пробуждая в нём решительность и чувство собственного достоинства, которое он часто подавлял в угоду наслаждению и комфорту викторианского «зачарованного замка».

Таким образом, коды «мужского» и «не-мужского» в постмодернистском неовикторианском романе А.С. Байетт варьируют в самом широком ключе - от примитивного маскулинного начала (мужчина как самец, сатир, кентавр и т.п.), до биологического аспекта (половой диморфизм; сильный мужчина - слабая женщина), юридически узаконенного традиционной викторианской моралью с её декларируемым «мужским приоритетом», и, наконец, восходят к утверждению единого гармоничного союза Матильды и Вильяма, созданного благодаря этически выверенным общечеловеческим качествам, которые во все времена могут быть равно присущи и женщинам, и мужчинам, - трудолюбие, решительность, интеллектуальность, самоотдача, труд, достоинство, верность, стойкость и талант.

\section{Литература}

Толстых О.А., Английский постмодернистский роман конца XX века и викторианская литература: интертекстуальный диалог: на материале романов А.С. Байетт и Д. Лоджа, Екатеринбург 2008.

Конькова М.Н., Поэтика жанра рассказа в творчестве А.Байетт, Екатеринбург 2010.

Байетт А.С., Морфо Евгения, ЛитМир, Электронная библиотека.

Откровение святого Иоанна Богослова, [в:] Библия. Книги священного писания Ветхого и Нового Завета.

Ремаева Ю.Г., Постфеминистская проза Британии на рубеже XX - XXI вв. (Феномен «чиклит»), Нижний Новгород 2007. 


\section{References}

Tolstyh O.A., Anglijskij postmodernistskij roman konca XX veka i viktorianskaâ literatura: intertekstual'nyj dialog: na materiale romanov A.S. Bajett i D. Lodža, Ekaterinburg 2008.

Kon'kova M.N., Poètika žanra rasskaza v tvorčestve A. Bajett, Ekaterinburg 2010. Bajett A.S., Morfo Evgeniâ, Litmir, Èlektronnaâ biblioteka.

Otkrovenie svâtogo Ioanna Bogoslova, [v:] Bibliâ. Knigi svâŝennogo pisaniâ Vethogo i Novogo Zaveta.

Remaeva Û.G., Postfeministskaâ proza Britanii na rubeže XX - XXI vv. (fenomen «čiklit»), Nižnij Novgorod 2007. 